\title{
Effects of pH, Dosage, Temperature and Mixing Speed on The Efficiency of Water Melon Seed in Removing the Turbidity and Colour of Atabong River, Awka-Ibom State, Nigeria
}

\author{
Ezeh Ernest ${ }^{1}$, Okeke Onyeka ${ }^{2}$, Nwosu David ${ }^{3}$, Okeakpu Blessing ${ }^{4}$ \\ ${ }^{1}$ Chemical Engineering Department, NnamdiAzikiwe University, Awka. \\ ${ }^{2}$ Plastic Production Unit, Scientific Equipment Development Institute, Enugu. \\ ${ }^{3}$ General Laboratory Unit, Scientific Equipment Development Institute, Enugu. \\ ${ }^{4}$ Electrical R \& D Unit, Scientific Equipment Development Institute, Enugu.
}

\begin{abstract}
Studies were carried out to determine the effects of operating parameters such as temperature, $\mathrm{pH}$, dosage and mixing speed on the efficiency of watermelon seed in removing the turbidity and colour of Atabong River, which serves the people of Eket and their environs in Akwa-Ibom State. Results obtained showed that at an ideal $\mathrm{pH}$ of 7.5, temperature of $25^{\circ} \mathrm{C}$, dosage of $0.6 \mathrm{~g} / \mathrm{l}$ and mixing speed of $120 \mathrm{rpm}$ the water melon coagulum removed turbidity and colour of the raw river water by $87.9 \%$ and $84.3 \%$ respectively. At this optimum conditions, water melon coagulum decreased the raw water turbidity from 67.7 to $8.18 \mathrm{NTU}$ and colour, 318 to $50 \mathrm{TCU}$. The findings have demonstrated the effectiveness of water melon seeds as a possible replacement for chemicals like alum and ferric salts normally used in coagulation-flocculation water treatment.
\end{abstract}

Keywords - Turbidity, Colour, Watermelon seed, Coagulation and Water.

\section{INTRODUCTION}

Water is undoubtedly the most vital natural resource. Water supply is a basic need required by living creatures and human beings (Chouhan et al., 2015). Water is the basis of life on earth. Developing countries and third world countries are facing potable water supply problems because of inadequate financial resources. In developing countries, 15 million infants die every year due to contaminated drinking water, poor hygiene and malnutrition (Deshpande, 2010). About $80 \%$ of illnesses in developing countries are directly connected with contaminated drinking water (WHO, 2004). Ground water, surface water and rain water are often the major sources of water availability in a community. Potable water, which is safe for drinking must be free from pathogenic organisms, toxic substances and excess of minerals and organic pollutants (Erinivasanet al., 1999). It must be colourless, tasteless and odourless in order to be attractive to consumers (Yongabi, 2010). World population increases year by year and reached about 7.3billion in 2013, where as an access of getting pure and safe water remains a problem especially for people who live in developing countries like Nigeria (Muhammad et al., 2015). The severity is much observed in rural dwellers whose source of drinking is surface water, which is usually not treated and this results in the transmission of water borne diseases (Megersa et al., 2004).

Ninety-seven percent of the earth's water is salt water of oceans and seas whereas most of the remaining 3 percent is captured in polar ice caps, glaciers, atmosphere or underground

(Coleman et al., 2001).Growing population, increased economic activity and industrialization has not only created an increased demand for fresh water but also resulted in severe misuse of this natural resource. Water resources all over would are threatened not only by over exploitation and poor management but also by ecological degradation (Thomas and Jungen , 2002). Water gets polluted from various sources. With increased industrial growth and urbanization, the volume of domestic and industrial effluent discharge, agricultural waste and urban run offs is steadily growing. Water bodies have an inherent capability to dilute pollutants which enter the system (Mirzaei et al., 2010). However, indiscriminate dumping of untreated sewage and chemical wastes directly into rivers, lakes and drains have made these water bodies unable to cope up with the pollutant loads (EPA, 2003).

The steady increase in the amount of water used and waste water produced by urban communities and industries throughout the world poses potential health and environmental problems (Coleman et al., 2001). In modern societies, proper management is a necessity, not an option. The purpose of waste water treatment is to remove the contaminants from water so that the treated water can meet the acceptable quality standards (Madhavi and Rajkumar, 2013). The quality standards usually depend on whether the water will be re-used or discharged into a receiving stream. Waste waters contain particles with a wide variety of 
shapes, sizes, densities etc., which influence their behaviour in water and therefore their capacity to be removed (Vlyssides et al., 2002).

The cost of waters treatment is increasing and the quality of river water is not stable due to suspended and colloidal particle load caused by anthropogenic activities and high storm run off during the rainy season (Rusal et al., 2006). Drinking water treatment involves a number of combined processes based on the quality of the water sources such as turbidity, amount of microbial load present in water and others include cost and availability of chemicals in achieving desired level of treatment (Muyibi et al., 2007). Conventional methods used for water purification include, coagulation, sedimentation, filtration, aeration and also disinfectant processes. Coagulation and flocculation are the processes used to remove the particles responsible for turbidity and colour (Kawamura, 1991). Turbidity is the cloudiness or haziness of a fluid caused by a large number of individual particles that are generally invisible to the naked eye, similar to smoke in air. The measurement of turbidity is a key test of water quality (Mann et al., 2007). Turbidity in open water may be caused by growth of phytoplankton, suspended matter such as clay, silt, finely divided organic and inorganic matter, soluble organic compounds and other microscopic organisms (Seyrig and Shan, 2007). Certain industrial activity such as quarrying, mining and coal recovery can generate very high level of turbidity from rock particles. A turbid water has muddy or cloudy appearance and it is aesthetically unattractive (Mann et al., 2007). In drinking water, the higher the turbidity level, the higher the risk that people may develop gastro intestinal diseases (Das et al., 2014). The suspended solids interfere with water disinfection with chlorine because the particles acts as shields for the virus and bacteria (Vlyssides et al., 2002). In water bodies such as lakes, rivers and reservoirs, high turbidity levels can reduce the amount of light reaching lower depths, which can inhibit the growth of submerged aquatic plants and consequently affect species which are dependent on them such as fish and shell fish (Mann et al., 2007). High turbidity levels can also affect the ability of fish gills to absorb dissolved oxygen. World Health Organisation established that the turbidity of drinking water should not be more than 5 NTU (EPA, 2006). The history of the use of coagulation process to remove turbidity in water is long. Depending on the application, chemical reagents are dosed into the water stream to increase coagulation and formation of flocs and effectiveness of settling before filtration (Javid et al., 2015). In drinking water treatment, the coagulation process is used to destabilize suspended particles and to react with organic materials in the raw water. Coagulation is a chemical reaction which occurs when a chemical or coagulant is added to water. The coagulant encourages collodial materials in the water to join together into small aggregates or flocs (Bratby, 2006). The coagulation process involves dosing of coagulant in water which results in destabilization of negatively charged particles and these destabilized particles must be incorporated into bigger flocs through flocculation (Masschelein, 1992).

Coagulation alters the colloidal particles in the water, so that they will be able to approach and adhere to each other to form larger flocs particles. Most colloids are stable because they possess a negative charge that repels other colloid particles before they collide with one another (Ebeling et al. 2004). Since colloids are stable because of their surface charge, in order to destabilize the particles, we must neutralize this charge such neutralization can take place by addition of an ion of opposite charge to the colloid. If not added the removal of suspended matter will be less efficient (Kawamura, 1991).

Common coagulants are aluminum sulphate, ferric chloride, polyaluminum chlorides and synthetics polymers. The use of coagulates such as alum is one of the commonest methods employed and it reduces the repulsive force between particulate matter, encouraging particle collision and floc formation (Moramudaii and Fernando, 2001). Recent studies have indicated a number of serious draw backs linked to the use of aluminium salts such as Alzheimer's disease associated with high aluminum residuals in treated water, excessive sludge production during water treatment and considerable changes in water chemistry due to reactions with $\mathrm{OH}^{-}$and alkalinity of water (Muhammad et al., 2015). In addition, the use of alum salts is inappropriate in some developing countries because of the high costs of imported chemical coagulants (Adejumo et al., 2013). Also, monomers of some synthetic organic polymers such as acrylamide have neurotoxic and strong carcinogenic properties. Because of this there has been considerable interest in the development of natural coagulants which are safe for human health and biodegradable (Ghebremichael, 2004). A number of studies have pointed out that the introduction of natural coagulants as a substitute for metal salts may ease the problems associated with chemical coagulants. Using natural coagulants instead of aluminum salts provide advantages such as lower costs of water production, less sludge production and ready availability (Daniyan et al., 2011).

Among plant materials that have been tested over the years, the seeds of moringa oleifera have been shown to be one of the most effective primary coagulants in water treatment or purification (Ali et al., 2010). It has been reported that the active coagulants in plant extracts are proteins, tannins and saponins, and they possess an ability to bind with other molecules tightly (Talbot et al., 1995). Recent study confirms that watermelon (Citrulluslanatus) seeds is a potential natural coagulant for water treatment because of its high protein, vitamin and mineral contents (Muhammadet al., 2015). Watermelon (Citrulluslanatus) is a member of the cucurbit family (Cucurbutaceae). The crop is grown commercially in areas with long frost-free warm 
periods and the crop may be established in the field by planting seeds or containerized transplants. (Misau and Yusuf, 2016) reported that the mineral elements present in water melon seeds which may have aided its coagulant properties were $\mathrm{Al}, \mathrm{Ca}, \mathrm{Mg}$ and $\mathrm{Fe}$ etc. Large populations in rural and semi-urban areas of Africa have no access to clean water. Waterborne diseases though a global health threat, is a feature of developing countries whose populace are compelled to use turbid and contaminated water for domestic purposes (Mahammad et al., 2015). Removal of colloidal and suspended particles present in water would be extremely beneficial as it would reduce majority of the problems associated with turbidity. The combinations of coagulation with other appropriate physiochemical treatment processes such as water initial $\mathrm{pH}$, coagulant dosage and mixing conditions results in efficiency of the coagulation - flocculation processes (Aguilar et al., 2009). During raw water treatment, the determinant of the coagulant dosage is one of the most important factors among various works conducted in unit processes (Zularisam et al., 2009). pH of the water, temperature, dosage and mixing speed have been shown to influence the efficiency of coagulation - flocculation processes in water treatment (Almubaddal et al., 2009). The aim of this study was to evaluate the efficacy of watermelon seed in removing turbidity and colour of Atabong River, AkwaIbom State, taking into cognizance the individual and interactive influences of coagulation - flocculation factors such as $\mathrm{pH}$, dosage, temperature, and stirring speed.

\section{MATERIALS AND METHODS}

Materials

Materials used in this work included watermelon seed cake, $\mathrm{N}$-hexane, Atabong river raw water, in Eket, Akwalbom State, soxhlet extractor, digital balance, electronic weighing balance,thermometer, oven, electric hot plate, beakers, flocculator, pipette, turbidimeter, conductivity meter and stop watch. All the chemicals used were of analytical grade.

\section{Methods}

i. Water melon seed (coagulant) preparation

Fresh seeds of watermelon (Citrulluslanatus) of the cucurbitaceae family were obtained from the local market (Urua-Akpan,Andem) in Uyo, Akwa-Ibom State, Nigeria. The fruits were sliced open using clean stainless steel laboratory knife. The seeds were washed severally with water, sun-dried for a week, sorted to remove bad ones, shelled and ground with high speed laboratory electric blender, packed in an air tight container. $150 \mathrm{~g}$ of the crushed seeds were then packed in a thimble and placed in a soxhlet extraction apparatus. 500ml of the n-Hexane was used to extract oil from the crushed seed in the column. The apparatus was left running for about 6hours and stopped when the extraction was complete. The cake was then washed with distilled water to remove residual n-Hexane, dried in an oven till constant weight and then sieved. The finer particles were used as the coagulant.

\section{ii. Sample water collection}

The raw water sample was collected from the Atabong River in Ibeno, Eket, Akwa-Ibom State, Nigeria. The water was collected from the river side by immersing a plastic container into the river until it was full. The cap was secured onto the container while it was still under the water. The water was then treated in the laboratory using the prepared coagulant.

iii. Water quality tests

(a) Turbidity

Turbidity of the water sample was determined using a turbid meter in accordance with international method of water quality measurement and the results recorded.

(b) Total Solid

Sample of the raw water were taken in $100 \mathrm{ml}$ beaker. A clean and dry crucible was weighed empty and the sample was then poured into it and reweighed. The respective weights were recorded and the crucible together with the sample water were then placed on a hot plate at $105^{\circ} \mathrm{C}$ to evaporate the water. When all the water evaporated, the crucible was allowed to cool down and reweighed together with the residue. The total solid present was then calculated using the equation:

TS $=100(\mathrm{~A}-\mathrm{B}) / 200 \mathrm{ml}$

Where: $\mathrm{A}=$ weight of (crucible + water) - weight of crucible empty

(crucible + residue $)$

B = weight of

\section{(c) Total Suspended Solid (TSS)}

Sample of the raw water was $100 \mathrm{ml}$ in a sample bottle. The weight of a dry filter paper was determined and the sample water was then filtered and the residue dried at $35-40^{\circ} \mathrm{C}$ in an oven. The new weight of the filter paper plus residue is then taken. The difference in the weight of the filter paper and with residue after drying was calculated and divided by total volume of the sample.

(d) Total Dissolved Solid (TDS)

This was obtained by taking the difference between TSS and TS or two-thirds of the conductivity using the conductivity meter.

(e) $p H$

The $\mathrm{pH}$ of the samples was determined using an electronic $\mathrm{pH}$ meter. 
(f) Colour

Colour of the water sample was carried out before and after treatment using a turbidity meter.

(g) Jar test

The jar test apparatus was used to assess coagulation and flocculation in the water samples. Five 1-litre beakers were used to study the effect of coagulant dosage on coagulation, the effect of $\mathrm{pH}$ on coagulation and the effect of stirring time and speed on coagulation. The following parameters were then measured in the filtrate after the coagulation was completed; turbidity, colour, $\mathrm{pH}$, TDS and conductivity. Five different weights of the coagulant were placed in each beaker, the first having $0.2 \mathrm{~g} / \mathrm{l}$ and the remaining four varying from $0.2-1.0 \mathrm{~g} / \mathrm{l}$ at $0.2 \mathrm{~g} / \mathrm{l}$ interval in order to determine the optimum dosage. The raw sample was then added to make up the $250 \mathrm{ml}$ mark and the jars were each placed in the jar test kit and the stirrers lowered into each. The stirring speed was setted at 2 minutes interval. After this was completed the samples were allowed to settle and the flocs filtered using a filter paper and the parameters listed above were measured on the filtrate. From the results obtained the dosage with the best results in colour and turbidity removal was taken as the optimum.

The procedure above was repeated, however a dose of $0.6 \mathrm{~g} / \mathrm{l}$ was maintained in all five beakers. The $\mathrm{pH}$ was varied from $5.5-8.0$ by the addition of few drops of $1 \mathrm{M} \mathrm{NaOH}$ into the beakers to increase the alkalinity. A few drops of $1 \mathrm{M} \mathrm{H}_{2} \mathrm{SO} 4$ solution was also added in the first two beakers to make it slightly acidic at 5.5. - 6.5. The $\mathrm{pH}$ at which the best turbidity and colour removal were observed at was taken to be the optimum $\mathrm{pH}$ for coagulation. Effect of temperature has also studied. The optimum dosage of $0.6 \mathrm{~g} / \mathrm{l}$ was used in all the beakers. The temperature of water was varied from $10-30^{\circ} \mathrm{C}$. The temperature at which the best turbidity and colour removal were observed at was taken to be the optimum temperature for coagulation.

Effect of mixing speed was also studied. The optimum dose of $0.6 \mathrm{~g} / \mathrm{l}$ was used in all the beakers. The mixing speed was then varied ranging from $40 \mathrm{rpm}-200 \mathrm{rpm}$ at $40 \mathrm{rpm}$ interval. After the coagulation-flocculation process was completed at each stage, the samples were filtered and the filtrate used to test for the operating parameters.

\section{RESULTS AND DISCUSSIONS}

Table.1: Physicochemical properties of the raw water from the Atabong River, Akwa-Ibom State.

\begin{tabular}{|l|l|l|}
\hline \multicolumn{1}{|c|}{ Parameter } & \multicolumn{1}{c|}{ Initial Values } & \multicolumn{1}{c|}{ WHO Standard Values } \\
\hline Temperature $\left({ }^{\circ} \mathrm{C}\right)$ & 28.50 & $25-30$ \\
\hline $\mathrm{pH}$ & 6.08 & $6.5-8.5$ \\
\hline Conductivity $(\mu \mathrm{S} / \mathrm{cm}$ & 481 & $1400 \mathrm{max}$ \\
\hline TDS $(\mathrm{mg} / \mathrm{l})$ & 193 & 933 max \\
\hline Turbidity $(\mathrm{NTU})$ & 67.70 & 5 max \\
\hline Colour $(\mathrm{TCU})$ & 318 & 15 max \\
\hline
\end{tabular}

From Table 1 above, it was observed that two main factors of measuring drinking water quality, turbidity and colour, were above WHO threshold levels making the water unfit for human consumption hence the need for treatment.

Table.2: Effect of watermelon seed coagulum doses on coagulation

\begin{tabular}{|c|c|c|c|c|c|c|c|}
\hline S/No. & Dosage $(\mathbf{g} / \mathbf{l})$ & $\begin{array}{c}\text { Temperature } \\
\left({ }^{\circ} \mathbf{C}\right)\end{array}$ & $\mathbf{p H}$ & $\begin{array}{c}\text { Conductivity } \\
(\mu \mathbf{S} / \mathbf{c m})\end{array}$ & $\begin{array}{c}\text { TDS } \\
(\mathbf{m g} / \mathbf{l})\end{array}$ & $\begin{array}{c}\text { Turbidity } \\
(\mathbf{N T U})\end{array}$ & $\begin{array}{c}\text { Colour } \\
(\mathbf{T C U})\end{array}$ \\
\hline 1. & 0.2 & 27.4 & 6.93 & 478 & 185 & 13.85 & 73 \\
\hline 2. & 0.4 & 27.8 & 6.88 & 488 & 177 & 11.30 & 68 \\
\hline 3. & 0.6 & 27.6 & 6.83 & 433 & 163 & 9.42 & 55 \\
\hline 4. & 0.8 & 27.5 & 7.18 & 460 & 179 & 12.95 & 70 \\
\hline 5. & 1.0 & 27.5 & 7.10 & 496 & 182 & 14.10 & 88 \\
\hline
\end{tabular}

Results of Table 2 shows that as doses of the natural coagulant were increased in the water, the physicochemical properties of the water with emphasis on turbidity and colour decreased remarkably. Research has shown that if too much or not enough coagulant are added to waste water, the removal of suspended water will be less efficient
(Muhammad et al., 2015). At a dose of $0.6 \mathrm{~g} / \mathrm{l}$ the highest turbidity and colour removal of 9.42NTU (86\%) and 55 TCU $(827 \%)$ respectively was observed. At dosage of $1.0 \mathrm{~g} / \mathrm{l}$, the least turbidity and colour removal of $14.10 \mathrm{NTU}$ (79\%) and 88 TCU $(72.3 \%)$ respectively was observed. The result shows that watermelon seed coagulum exhibited 
highly efficient reduction in turbidity and colour of river water at $0.6 \mathrm{~g} / \mathrm{l}$. Although both the turbidity and colour values at dosing of $0.6 \mathrm{~g} / \mathrm{l}$ was still above the WHO recommended levels for safe drinking water, the results has substantiated the efficacy of water melon seeds as a natural coagulant. The high protein, tannin and mineral contents of the water melon seed could have been responsible for its coagulant properties (Gwana et al., 2014; Musau and Yusuf, 2016). The mechanism of coagulations with the seeds of watermelon consist of absorption and neutralization of the colloidal positive charges that attract the negatively charged impurities in the water (Sotheeswaran et al., 2011). When the coagulant dose is too small the coagulation is insufficient resulting in a poor effect of coagulation. When the coagulant is too high, the particles in the raw water are enclosed by too much coagulant and as a result their surfaces are saturated resulting in reduction of particles to combining on coagulation and reach stability, in which it is hard for the particles to coagulate (Gregory and Guibail, 1991).

Table.3: Effect of pH on coagulation

\begin{tabular}{|c|c|c|c|c|c|c|}
\hline S/No. & $\mathbf{p H}$ & Temperature $\left({ }^{\mathbf{o}} \mathbf{C}\right)$ & $\begin{array}{c}\text { Turbidity } \\
(\mathbf{N T U})\end{array}$ & $\begin{array}{c}\text { Conductivity } \\
(\mu \mathbf{S} / \mathbf{c m})\end{array}$ & TDS $(\mathbf{m g} / \mathbf{l})$ & Colour $(\mathbf{T C U})$ \\
\hline 1. & 5.5 & 26.9 & 18.11 & 788 & 200 & 90 \\
\hline 2. & 6.5 & 27.3 & 11.60 & 730 & 186 & 69 \\
\hline 3. & 7.5 & 27.0 & 9.78 & 755 & 174 & 58 \\
\hline 4. & 8.5 & 27.2 & 18.42 & 700 & 188 & 73 \\
\hline 5. & 9.0 & 27.1 & 21.07 & 686 & 195 & 97 \\
\hline
\end{tabular}

The recommended $\mathrm{pH}$ range for efficient coagulation is usually between 6.0 to 8.5 (Othman et al., 2008). However, the $\mathrm{pH}$ of the raw river water was adjusted from 5.5 to 9.0 to observe its effect on effective coagulation of the natural coagulant at $0.6 \mathrm{~g} / \mathrm{l}$. When the $\mathrm{pH}$ of the raw water was made more acidic at 5.5, the values of the turbidity and colour removal were 18.11 NTU and 90TCU, thus this alteration of $\mathrm{pH}$ decreased the efficiency of the coagulant by $13 \%$ and $11 \%$ respectively from the values of $0.6 \mathrm{~g} / \mathrm{l}$ obtained in Table 2. Also, when the $\mathrm{pH}$ of the raw water was made slightly basic, at 9.0, the values of the turbidity colour removal were 21.07 NTU and 97 TCU and this revealed a decrease in efficiency of the normal coagulant by
$17 \%$ and $13 \%$ respectively. At $\mathrm{pH}$ of 7.5 the best values of removal of turbidity and colour from the water was $85.5 \%$ and $81.8 \%$ respectively. At this $\mathrm{pH}$, the decrease in coagulant efficiency in removing turbidity and colour in the raw water was less than $2 \%$ from the values of Table 2 at $0.6 \mathrm{~g} / \mathrm{l}$. The results of Table 3 shows that $\mathrm{pH}$ that is too low may not allow efficient coagulation process to proceed while a high $\mathrm{pH}$ can cause a coagulated particle to redisperse. The size of the coagulated particles is also affected by $\mathrm{pH}$, which in turn determines the density of the flocculated slime and its tendency and rate of settling out (Bratby, 2006).

\section{Effect of temperature on coagulation}

Table.4: Effect of temperature on coagulation efficiency of watermelon seed cake at $0.6 \mathrm{~g} / \mathrm{l}$

\begin{tabular}{|c|c|c|c|c|c|c|}
\hline S/No. & $\begin{array}{c}\text { Temperature } \\
\left({ }^{\circ} \mathbf{C}\right)\end{array}$ & $\mathbf{p H}$ & $\begin{array}{c}\text { Turbidity } \\
(\mathbf{N T U})\end{array}$ & $\begin{array}{c}\text { Conductivity } \\
(\mu \text { S/cm) }\end{array}$ & TDS (mg/l) & Colour (TCU) \\
\hline 1. & 10 & 6.78 & 12.44 & 460 & 180 & 67 \\
\hline 2. & 15 & 6.71 & 11.92 & 473 & 173 & 63 \\
\hline 3. & 20 & 6.80 & 11.18 & 430 & 176 & 60 \\
\hline 4. & 25 & 6.54 & 8.17 & 471 & 176 & 50 \\
\hline 5. & 30 & 6.72 & 10.94 & 478 & 181 & 64 \\
\hline
\end{tabular}

Water temperature has been found to be an important factor affecting coagulants in water treatments (Zhang et al., 2009). The results of Table 4 shows that when the temperature of the raw water was reduced to $10^{\circ} \mathrm{C}$, the values of the removal of turbidity and colour was 12.44 NTU and 67 TCU, which showed a decrease in the efficiency of the coagulant by $4.36 \%$ and $3.8 \%$ respectively when compared to the results of Table 2 when the temperature of the water was $27.6^{\circ} \mathrm{C}$ at $0.6 \mathrm{~g} / \mathrm{l}$. Also, when the temperature of the raw water was increased to $30^{\circ} \mathrm{C}$, the values of the turbidity and colour removal were 10.94 NTU and 64 TCU and these values revealed a decrease in the efficiency of the coagulant by $2.2 \%$ and $2.8 \%$ respectively compared to the results of Table 2 at temperature of $27.6^{\circ} \mathrm{C}$. The best result of removal of turbidity and colour were 8.34 NTU and 50 TCU respectively at $25^{\circ} \mathrm{C}$. This suggested an increase in the efficiency of the coagulant to removing turbidity and colour of the raw water by $1.79 \%$ and $1.6 \%$ respectively when compared to the results of Table 2 at $27.6^{\circ} \mathrm{C}$ and a dose of $0.6 \mathrm{~g} / \mathrm{l}$. The effect of temperature on the settling process is well known. It has been reported that decrease in temperature $\left(0-24^{\circ} \mathrm{C}\right)$, impairs the flocs 
strength and virtually the flocs formation efficiency and thus results in bad settling. Therefore low temperature slow down the coagulation processes which results in decrease in aggregation rate and prolonged flocculation time (FitzPatrick et al., 2004). As the temperature increase, viscosity of the raw water decreases and brown movement become fierce gradually as a result of hydrolysis of mineral ion and increased competition for bonding by the macromolecules and this accelerates the coagulation processes (Stephenson and Doff, 1996; Misau and Yusuf, 2016). At high temperatures (above $30^{\circ} \mathrm{C}$ ), breakage in terms of floc size reduction is greater (Bratby, 2006).

\section{Effect of mixing speed}

Table.5: Effect of mixing speed on coagulation efficiency of watermelon seed cake at $0.6 \mathrm{~g} / \mathrm{l}$

\begin{tabular}{|c|c|c|c|c|c|c|c|}
\hline S/No. & $\begin{array}{c}\text { Mixing speed } \\
\mathbf{r p m}\end{array}$ & $\mathbf{p H}$ & $\begin{array}{c}\text { Temperature } \\
\left({ }^{\circ} \mathbf{C}\right)\end{array}$ & $\begin{array}{c}\text { Conductivity } \\
(\mu \mathbf{S} / \mathbf{c m})\end{array}$ & $\begin{array}{c}\text { TDS } \\
(\mathbf{m g} / \mathbf{l})\end{array}$ & $\begin{array}{c}\text { Turbidity } \\
(\mathbf{N T U})\end{array}$ & $\begin{array}{c}\text { Colour } \\
(\mathbf{T C U})\end{array}$ \\
\hline 1. & 40 & 6.46 & 26.8 & 505 & 210 & 13.14 & 67 \\
\hline 2. & 80 & 6.51 & 27.1 & 537 & 225 & 11.80 & 64 \\
\hline 3. & 120 & 6.62 & 27.2 & 563 & 238 & 9.06 & 54 \\
\hline 4. & 160 & 6.57 & 27.5 & 568 & 242 & 10.71 & 62 \\
\hline 5. & 200 & 6.81 & 27.49 & 589 & 251 & 13.68 & 70 \\
\hline
\end{tabular}

Mixing speed is one of the important factors in achieving higher flocculation efficiency during the coagulationflocculation process (Othman et al., 2008).

Table 5 shows that at a lower mixing speed of 40rpm, at $0.6 \mathrm{~g} / \mathrm{l}$ dosage, the removal of turbidity and colour of the raw river water was $13.14 \mathrm{NTU}$ and 67TCU, which buttressed a decrease in the efficiency of coagulation by $5.4 \%$ and $3.8 \%$ respectively compared to result of Table 2 .

Also at a higher mixing speed of 200rpm, the values of turbidity and colour removal of the raw water were 13.68 NTU and 70 TCU, thus suggesting a decrease in the efficiency of the coagulant by $6.2 \%$ and $4.7 \%$ respectively at dosing of $0.6 \mathrm{~g} / \mathrm{l}$. The best result of the mixing speed was at $120 \mathrm{rpm}$, with values of $9.06 \mathrm{NTU}$ for turbidity and 54 TCU for the colour of the water at $0.6 \mathrm{~g} / \mathrm{l} \mathrm{dosing}$. At this mixing speed (120rpm) the efficiency of the coagulant to remove turbidity and colour of the raw water increased by $0.6 \%$ and $0.3 \%$ respectively compared to results in Table 2 . Hence, at lower mixing speeds (below 80rpm), the flocs formed in coagulation - flocculation processes were easily broken and the removal efficiency could decrease while at higher mixing speed (above 160rpm) coagulation efficiency was not improved due to increased shearing of the flocs.

\section{CONCLUSION}

Coagulation flocculation treatment of water using watermelon seeds have been shown to be suitable for removing the turbidity and colour of water when the operating parameters are optimized. Considering the fact that watermelon coagulum can be produced locally, its use in water treatment should be encouraged. This will inevitably reduce the high cost and health hazards associated with chemical water treatments currently in use. The technologies involved are economical, traditional and easy to implement and ideal for rural areas. The process being biological in nature does not generate any nontreatable wastes.

\section{REFERENCES}

[1] Adejumo M., Oloruntoba, E. O. and Sridhar M. K. (2013).Use of Moringa Oleifera seed powder as a coagulant for purification of water from unprotected sources in Nigeria. European Scientific Journal 9(24): $241-253$.

[2] Ali E.N., Suleyman A. M., Hamzah M., Alam M.D. and Salleh M.M. (2010).Production of natural coagulant from moringaoleifera seed for application in treatment of low turbidity water.J. water resource and protection, 2:259-266.

[3] Almubaddal F., Alromaihi, K. and Ajbar A. (2009).Performance optimization of coagulation/flocculation in the treatment of waste water from poly vinylchloride plant. J. Hazard Mater, 161(1): 431 - 437.

[4] Bas W., Anzalone G.C. and Joshua M.P. (2014).Open-Source mobile water quality testing platform. Journal of water sanitation and hygiene for Development, 4(3): 532-537.

[5] Bratby J. (2006). Coagulation and flocculation in water and waste water treatment.IWA publishing, Seatle, London. pp. $81-86$.

[6] Chauhan S. and Gupta K.C. (2015).Purification of drinking water with the application of natural extract. Journal of Global Biosciences, 4(1): 1861 - 1866.

[7] Coleman J., Hiench K., Garbutt K., Sexstone A. and Skovsen J. (2001).Water, Air and pollution. J. Bio Res. Technology 10(1): 2167 - 2172.

[8] Daniyan Y.S., Ememaduku A.M. and Eru E.O. (2011). The use of Moringa seed extract in water purification. International Journal of Research in Ayrveda\& Pharmacy. 2(4): 1265 - 1277.

[9] Deshpade L. (2010). Water quality analysis laboratory methods.National Environmental Engineering Research conference, New Delhi. pp. 137 - 139.

[10] Ebeling J.M., Ogden S.R., Sibrell P. and Rishel K. (2004). Application of chemical coagulation aids for 
the removal of suspended solids and phosphorus from microscreen effluent discharge of an intensive recirculating aquaculture system: N. American J. of Aquaculture. 66:198-207.

[11] Environmental Protection Agency (2003). Effects of Acid Rain: Lakes and Streams. Washington D.C. pp. $81-85$.

[12] Environmental Protection Agency (2006). Quality Criteria for water. Document No. 440/5-86-001. Washington D.C.

[13] FitzPatrick C.S., Fradin E. and Gregory J. (2004). Temperature Effects in Flocculation using different coagulants Water Sci. Technology., 50(12): 171 - 175.

[14] Ghebremichael K. A. (2004). Moringa seed and pumice as alternative natural materials for drinking water treatment, unpublished Ph.D thesis, KTH Land and Resource Engineering.

[15] Gregory J. and Guidail B. F. (1991).Effects of dosing and mixing conditions on polymer flocculation of concentrated suspensions. Chem. Eng. Co., 108: 3 21.

[16] Gwana A., Bako M., Bagudu B., Sadiq A. and Abdullahi M. (2014). Determination of physico chemical, Vitamins, Minerals and Proximate composition of varieties of watermelon seed cultivated in Borno state, North East, Nigeria. International Journal of Nutrition and food sciences, $238-245$.

[17] Javid A.H., Malakotia M. and Mehdipour M. (2015).Investigation of Ozone and coagulant materials (Aluminium Sulfate, Ferric Chloride and poly aluminium chloride and lime) efficiency in "kermarkonk" industry waste water treatment. Environmental Health Engineering and Management Journal, 2(1): $1-6$.

[18] Kawamura S. (1991). Effectiveness of natural poly electrolysis in water treatment. Journal of the American water works Association, 83(10): 8891.

[19] Madhavi T.F. and Rajkumar R. (2013).Utilization of natural coagulant for reduction of turbidity from waste water. International J. Chem. Tech. Research., 5(3): $1119-1123$.

[20] Mann A.G., Tom C.C., Higgins C.D. and Lodrigues L.C. (2007). The association between drinking water turbidity and gastrointestinal illnesses: a systematic review. BMC Public Health 7(256) $1-7$.

[21] Masschelein W. (1992).Unit processes in drinking water treatment ISBN 08247 - 87785 USA p.635.

[22] Mergersa S.M., Beyene A., Ambelu A. and Woldeab B. (2004). The use of indigenous plant species for drinking water treatment in developing countries: a review. Journal of biodiversity and environmental sciences. 5(3): $269-281$.

[23] Mirzaei N.H. and Asadi K.F. (2010).Moringa: A miracle native iron: Research Institute of forests and Rangelands of Iran. pp. $81-83$.
[24] Misau I.D. and Yusuf A.A. (2016).Characterisation of watermelon seed used as water treatment coagulant. Journal of Advanced studies in Agricultural, Biological and Environmental Sciences, 3(2): 22 - 29.

[25] Moramudaii M. and Fernando P. (2001).Use of seeds of moringaoleifera to clarify turbid waters and waste waters.Vidyodaya j. Sci., 10: 167 - 182.

[26] Muhammmad I.M., Abdulsalam S., Abdulkarim A. and Bello A. (2005). Watermelon seed as a potential coagulate for water treatment. Global Journal of Researches in Engineering: 15 (1): 1-8.

[27] Muyibi S.A., Ali, E. N. and Salleh H. M. (2009).MoringaOleifera seeds as natural coagulant for water treatment. Thirteen international water Technology conference, 13(2): $1-10$.

[28] Othman Z., Bhatia S. and Ahmad A.L. (2008). Influence of the settleability parameters for palm oil mill effluent pretreatment by using MoringaOleifera seeds as an environmental friendly coagulant, Interference conference on Environment, Malaysia 1 9.

[29] Rusal M.G., Faisal I. and Kamal K.M.M. (2006). Environmental pollution generated from process industries in Bangladesh. J. Environ. Pollut. 28(2): 44 -61 .

[30] Seyrig G. and Shan W. (2007). Coagulation and Flocculation: colour removal, unpublished Ph.D Thesis, College of Engineering, Michigan, pp. $81-86$.

[31] Sotheeswaran S., Nand V., Mata Kite M. and Kanayathu K. (2011).MoringaOleifera and other local seeds in water purification in developing countries. Res J. Chem Environ 15(2): 135 - 138.

[32] Srinvasan P.T., Vivaragharan T. and Sirbramanian K.S. (1999).Aluminium in drinking water: an overview, Water SA; 25(1): 47 - 49.

[33] Stephenson R.J. and Duff S.J.B. (1996). Coagulation and precipitation of a mechanical pulping effluent: Removal of Carbon, Colour and turbidity. Water Res. 30:781.

[34] Talbot B., Narasiah K. and Ndebigenesere A. (1995). Active agents of turbid waters using moringaoleifera water Res., 29: 703 - 710.

[35] Thomas K. and Jurgen B. (2002).Phosphorus reduction in a shallow hypereutrophic reservoir by in lake dosage of ferrous iron.Water Res., 36: 4525 4534.

[36] Vlyssides A.G., Karlis P.K., Rori N., and Zorpas A.A. (2002).Electrochemical treatment in relation of $\mathrm{pH}$ of domestic waste water using electrodes. J. Hazard Mater., 95: 215 - 226.

[37] WHO (2004).Guidelines for drinking water quality $3^{\text {rd }}$ Edition vol. 1 pp $371-372$.

[38] Yongabi K.A. (2010). Bio-coagulants for water and waste water purification: a review. International review of Chemical Engineering., 2(3): 444 - 458. 
[39]Zhang B.J., Cui C.U., Xiao F. and Huang J. H. (2009).Effect of low temperature on coagulation kinetics and floc surface morphology using alum. Desalination, 237: $201-213$.

[40]Zularisam A. W., Ismail A. F., Salim M. R., Salcinah M. and Matsoora T. (2009). Application of coagulation-ultrafiltration hybrid process of drinking water treatment optimization of operating conditions using experimental design, Sep.Purif.Technol, 65(2): $193-195$. 